\title{
Has high knowledge of HIV/AIDS among the youth translated into positive sexual behavior in Northern Uganda?
}

\author{
Gideon Rutaremwa \\ Department of Population Studies, Makerere University \\ grutaremwa@isae.mak.ac.ug \\ James P.M Ntozi \\ Department of Population Studies, Makerere University \\ jntozi@isae.mak.ac.ug
}

\author{
Nambatya Diana \\ Partners in Population and Development Africa Regional Office \\ dnambatya@ppdsec.org, ordianabn2000@yahoo.com
}

\section{Abstract}

Uganda has been hailed for combating the HIVIAIDS epidemic from an $18 \square$ prevalence in 1992 to only 6.I $\square$. However, it rose to 6.4 $\square$ in 2004/5. Northern Uganda, which faced political turmoil and insurgency for 20 years, presents a mixed picture, with the highest prevalence, 9.4 $\square$, in the country. The main objective of the research was to investigate the relationship between socio-economic characteristics, knowledge and practices towards HIV/AIDS among youth in Northern Uganda Region. Data on 910 youth from Northern Uganda was extracted from the national Uganda demographic and health survey of 2006. Univariate, bivariate and multivariate analyses were applied. Results from multivariate analysis show that age, residence, education, occupation, knowledge of one who has died from or is sick with AIDS and risk perceptions were significant predictors of condom use at last sex. Only sex was observed to be significantly related to willingness to be tested for HIV. In conclusion, although knowledge about HIV is important, translating it into behavior or practices to prevent or protect individuals from contracting HIV is essential. There is a need for sensitizing youth on the need to adopt safe sexual behavior. A comprehensive school sex education programme that scales up the understanding of safe behavior and enables girls to negotiate for safe sex will be required. The findings have important implications for the development of primary HIV/AIDS prevention programs for youth in war-torn areas.

Keywords: Knowledge, HIV/AIDS, youth, positive, sexual behavior 


\section{Résumé}

L'Ouganda abstrait a été grêlé pour combattre l'épidémie de HIV/SIDA de la prédominance de I8 en 1992 à 6.I $\square$. Cependant il a maintenant atteint 6.4 dans 2004/5. L'Ouganda nordique qui a fait face à l'agitation et à l'insurrection politiques pendant les 20 dernières années de présents une image mélangée avec la plus forte présence de $9.4 \square$ dans le pays. L'objectif principal de la recherche était d'étudier le rapport entre les caractéristiques, la connaissance et les pratiques socio-économiques vers le HIV/SIDA parmi la jeunesse dans la région nordique de l'Ouganda. Des données sur la jeunesse 910 d'Ouganda nordique ont été extraites à partir de l'Ouganda national démographique et de l'enquête de santé de 2006. Des analyses univariables, bivariate et multivariables ont été appliquées. Les résultats de l'analyse multivariable prouvent que l'âge, la résidence, l'éducation, le métier, la connaissance d'un mort ou le malade du SIDA et des perceptions de risque étaient les facteurs prédictifs significatifs de sexe d'utilisation de condom enfin. On a observé seulement le sexe pour être sensiblement relié avec la volonté de déterminer HIV. En conclusion bien que la connaissance au sujet d'HIV soit importante, la traduction de lui dans le comportement ou les pratiques d'empêcher ou protéger des individus contre contracter HIV est essentielle. Il y a besoin de sensibiliser la jeunesse sur la nécessité d'adopter le comportement sexuel sûr. Un programme d'éducation de sexe d'école d'enseignement secondaire qui mesure vers le haut de l'arrangement du comportement sûr et permet à des filles de négocier pour le sexe sûr sera exigé. Les résultats ont des implications importantes pour le développement des programmes primaires de prévention du SIDA d'HIV pour la jeunesse dans des secteurs déchirés par guerre.

Mots clés: La connaissance, HIV/SIDA, jeunesse, positif, comportement sexuel

\section{Introduction}

Acquired Immune Deficiency Syndrome (AIDS) is caused by a human immunodeficiency virus (HIV) that weakens the immune system, making the body susceptible to opportunistic diseases that often lead to death. The predominant mode of HIV transmission is through heterosexual contact, followed by perinatal transmission, where the mother passes the virus to the child during pregnancy, delivery or breastfeeding. Other modes of transmission are through infected blood and unsafe injections.

HIV/AIDS is a global challenge that has threatened the very existence of the human race. At present, there is no country in the world without HIV cases (WHO 1995). The African continent is said to hold the vast majority of the world's HIV infected population. It is estimated that in 2007, of the $\square .0$ million people living with HIV/AIDS, 22.0 million of them lived in sub-Saharan Africa, (UNAIDS, 2008). More than 25 million people had died of AIDS worldwide since 1981. Africa had 11.6\% AIDS orphans. Women accounted for $50 \%$ of all adults living with HIV worldwide and for 59\% in sub-Saharan Africa. Young people (under 25 years old) accounted for half of all new infections worldwide, (UNAIDS, 2008).

Uganda has experienced a severe and devastating epidemic of HIV infec- 
tion and AIDS for more than a quarter of century. The epidemic started on the shores of Lake Victoria in Rakai District. Thereafter, HIV infection spread quickly, initially in major urban areas and along highways. By 1990s, HIV had reached all districts in the country, resulting in what is classified as a generalized epidemic. As in other countries in sub-Saharan Africa, Uganda's HIV/AIDS epidemic is predominantly spread through heterosexual contact.

The impact of the disease has been mainly felt through the escalating morbidity and mortality that disproportionately affects women during the prime of their productive life. The consequences of the epidemic span across all spheres of life (individuals and communities nationwide). It has imposed a severe and unsustainable burden on the meager health sector resources, as funds are diverted from other areas to HIV prevention and AIDS care and treatment services. HIV infection has also given rise to an epidemic of opportunistic infections, notably tuberculosis (TB). Treatment of some of these opportunistic infections is more expensive than that of AIDS.

In Uganda, the national HIV prevalence peaked at around $15 \%$ in 1991 and fell to $5 \%$ in 200 I (UNAIDS 2002). According to the results of the Uganda HIV/AIDS Sero-Behavioural Survey (UHSBS) of $2004 / 5$, the national prevalence of HIV is estimated at $6.4 \%$. HIV/ AIDS therefore, continues to represent a significant public health problem. A major concern is that the AIDS epidemic is influencing the nature and quality of health care through occupational transmission, (Verbeck et al., 1991).
All persons between 15 and 24 years old are defined as youth (WHO, 1989). The youthful stage is a time when most people are beginning to experiment with sex and are exposed to the dangers inherent in the process. The youth in Uganda as a group are highly at risk of HIV infection. Youth constitute a considerable proportion of the world's population and are one of the most dynamic human resource bases. Youth go through both physical and emotional stages of transition from childhood to adulthood. Previous studies of sexual behavior among Ugandan youth indicate an early initiation of sexual activity. An adolescent reproductive health survey revealed that the median age at first sexual intercourse was lower for females than for males (PEARL, 2000). In addition, $14 \%$ of youth had had sex before they turned age 15 , and $6 \square \%$ of women and $47 \%$ of men had had sex before 18 (UBOS and Macro International, 2006). This behavioral pattern has important implications for HIV transmission among female adolescents.

Youth are at the centre of the global HIV/AIDS pandemic. They are the world's greatest hope in the struggle against this fatal disease. Today's youth have inherited a lethal legacy that is killing them. An estimated II.8 million youth aged $15-24$ years are living with HIV/AIDS. Each day, nearly 6,000 youth between the ages of 15-24 years are infected with HIV. At $25 \%$, Uganda has one of the highest teenage pregnancies in the world, (UBOS, 2007). It also shows that condom use among youth leaves a lot to be desired.

Uganda has been hailed for combating the HIV/AIDS epidemic from $18 \%$ 
prevalence in 1992 to $6.1 \%$ in 2000 $(\mathrm{MOH}, 200 \square)$. However, the epidemic rose to $6.4 \%$ in $2004 / 5$. According to the results of the Uganda HIV/AIDS Sero-Behavioural Survey (UHSBS) of 2004/5, HIV prevalence in Northern Central is $8.2 \%$, North East is $0.5 \%$ and West Nile is 2. $\square \%$. Because of prolonged civil conflict and insurgency for two decades, Northern Central Uganda has the highest prevalence in the country (MOH 2005).

However, it has also been reported that a number of youth are reluctant to undergo positive behavior change in spite of extensive information through awareness campaigns. In order to realize greater success of programmes in Northern Uganda it is necessary to address the reasons for the observed reluctance.

This paper seeks to investigate whether the high knowledge among youth has led to positive sexual behavior in Northern Uganda. Specifically, the paper will establish the knowledge of HIV/AIDS among youth, study their attitudes towards HIV/AIDS, identify their practices and explore the relationship between socio economic factors.

\section{Data and methods}

This paper is based on a study that was conducted in Northern Uganda and targeted youth between the ages of 15 and 24 years. Northern Uganda is composed of West Nile (with Arua, Adjumani, Moyo, Nebbi, and Yumbe districts) Northern Central (with Lira, Apac, Gulu, Kitgum, and Pader districts) and North East (with Kaberamaido, Katakwi, Kotido, Kumi, Moroto, Nakapiripirit and Soroti districts).

Secondary data was used from the
Uganda Demographic and Health survey (UDHS), conducted by the Uganda Bureau of Statistics (UBOS) and Macro International 2006. This survey was conducted with the general objective of providing information on demographic, health and family planning status and trends in the country. Respondents from Northern Uganda Region in the age group 15 - 49 were asked questions on their knowledge, attitudes and practices relating to HIV/AIDS. The analysis will therefore be limited to the sub sample of 910 youth in the age group 15 - 24 years.

Analysis of the data went through three stages, namely univariate, bivariate and multivariate.

Cross tabulations were run to establish the association between knowledge and attitudes about AIDS and sexual behaviour. Other variables expected to influence individual behaviour in the form of socio-economic characteristics were age, sex, marital status, income, education level, occupation, cultural beliefs, residence and employment status. The association of these variables with the intermediate variables of knowledge and attitudes towards AIDS was established. The dependent variable behavioural change was measured in terms of condom use and willingness to go for an HIV test.

The significance of the associations between the variables was established by conducting the chi-square tests. A pvalue of 0.05 and less indicated the level of significance. At this level, the binary logistic regression model was fitted to examine the relationship between the sexual behavior (dependent variable) and the independent variables (knowledge and attitudes). The method was 
deemed appropriate for analysis because the dependent variable is dichotomous or binary in nature (change or no change in behavior). The model was used to calculate the odds: ratios for the exposure categories of the main study variables carried out.

The binary logistic model (Hair et al., 1998) was fitted in this form:

$$
\log \frac{p}{(1-p)}=B_{0}+B_{1} X_{1}+\ldots B_{n} X_{n}
$$

Where:

$B_{\mathrm{S}}=$ the estimated coefficients

$X_{S}=$ the independent variables

$\mathrm{n}=$ number of variables

$\mathrm{p}=$ probability of youth changing behaviour.

The model shows the likelihood of a youth changing his sexual behavior relative to a reference category for each of the independent variables. Independent variables were categorized and for each category dummy variables were created. This was done in reference to the category hypothesized with the lowest likelihood for behavior change called the reference category. The likelihood of a youth changing his sexual behavior varies across socio-economic and demographic characteristics. However, the odds ratios were assumed to remain constant across the exposure duration.

The odds ratio is the ratio of odds that an event will occur to the odds that it will not occur. A factor less than one means reduced odds while that greater than I means increased odds. Variable categories with $\mathrm{p}$-value 0.05 were deemed significant. The R-statistic which is used to analyze the partial cor- relation between the dependent variable and each of the independent variable ranges between the dependent variable and each of the independent variables, ranges between $-I$ and $+I$. A positive value indicates that as a dependent variable increases in value so does the likelihood of the event occurring and the reverse is true for the negative value. The $\mathrm{R}$-statistic measures the partial contribution of the variable to the model.

\section{Results}

Univariate analysis revealed a predominantly female (59\%) population; the majority of whom were young adults (56\%) aged $20-24$ years. Most (57\%) of the respondents lived in urban areas and a significant majority were males $(75.8 \%)$. Most youth were peasants (48\%) and clerical workers (17.4\%) were the least. $44 \%$ of the youth had attained primary education and the majority were Catholics (48.[\%). 67\% of the youth were married and only $9.8 \%$ had never married. Most youth $(47 \%)$ were from the West Nile Region, $41 \%$ were from the North Central and only $11 \%$ were from North East Region.

Most of the respondents were young adults aged 20-24 years. While more females than male youth had never been to school, more male than female youth were living in urban areas and more female youth were living in rural areas than in urban areas. Sex was a big determinant of level of education attained by respondents. While more men than women had post primary education, more female than male youth had no education. Catholics formed the majority of the study group 
and Moslems were the least. While the majority of the respondents were from the West Nile and North Central region, the North East region had the least respondents in the study. Majority of the female respondents were peas- ants while most males were clerical and casual workers. More males than females had never been married before and more female youth were divorced, separated, or widowed.

Table I Percentage distribution of respondents according to background characteristics by sex

\begin{tabular}{|c|c|c|c|}
\hline Background characteristics & $\begin{array}{l}\text { Males } \\
(\mathrm{n}=\square 70)\end{array}$ & Females $(n=540)$ & $\begin{array}{l}\text { Both sexes } \\
(n=9 \mid 0)\end{array}$ \\
\hline \multicolumn{4}{|l|}{ Age group } \\
\hline $15-19$ & 47.8 & 40.0 & 4ฤ.9 \\
\hline $20-24$ & 52.2 & 60.0 & 56.1 \\
\hline \multicolumn{4}{|l|}{ Residence } \\
\hline Urban & 75.8 & 41.4 & 58.6 \\
\hline Rural & 24.2 & 58.6 & 41.4 \\
\hline \multicolumn{4}{|l|}{ Sub-Region } \\
\hline North East & I & 8.7 & 11.2 \\
\hline North Central & $\square 8.4$ & 45.2 & 41.8 \\
\hline West Nile & 48.0 & 46.1 & 47.0 \\
\hline \multicolumn{4}{|l|}{ Education } \\
\hline None & 5.6 & 18.9 & I $\mathrm{Z} .2$ \\
\hline Primary & $\square 9.1$ & 47.0 & 4ロ.7 \\
\hline Secondary & $\square 7 . \square$ & $2 \square .5$ & 29.4 \\
\hline Tertiary & 18.0 & 10.6 & IQ.7 \\
\hline \multicolumn{4}{|l|}{ Religion } \\
\hline Catholics & 49.1 & 47.4 & 48. $\square$ \\
\hline Protestants & $\square 6.0$ & ए.2 & $\square 4.4$ \\
\hline Moslems & 14.9 & 19.4 & 17.5 \\
\hline \multicolumn{4}{|l|}{ Occupation } \\
\hline Peasants & 21.1 & 52.7 & 48.1 \\
\hline Business & $\square 0.5$ & 19.9 & 20.2 \\
\hline Clerical work & 18.2 & 16.6 & 17.4 \\
\hline Casual work & $\square 0.2$ & 10.8 & 20.5 \\
\hline \multicolumn{4}{|l|}{ Marital status } \\
\hline Never married & 16.0 & Q.० & 9.8 \\
\hline Currently married & 62.5 & 70.8 & 66.7 \\
\hline Cohabiting & 14.6 & 18.8 & 16.7 \\
\hline Separated/Divorced/widowed & 6.90 & 7.1 & 6.8 \\
\hline ALL & 100.0 & 100.0 & 100.0 \\
\hline
\end{tabular}


Results presented in Table I show that most respondents had heard about AIDS (97.7\%) and knew who was sick or dead with AIDS (86\%) and knew who were at risk of HIV infection $(65.5 \%)$. All male youth had heard about AIDS and a high percent of them knew someone dead or sick with AIDS $(92.2 \%)$ and were at risk of infection (7I.7\%). The table shows that male youth have significantly high knowledge of deaths due to HIV/AIDS or patients with HIV/AIDS than their female counterparts $(p=0.002)$. This could be because of the majority of the male youth living in urban areas where HIV/ AIDS information is more available compared to the rural areas where their female youth mostly live. Greater mobility among male than female youth may be another reason.

At bivariate stage of analysis, the
Pearson chi-square test was used to test the hypotheses. Results presented in Table 2 show that most respondents had heard about AIDS (97.7\%), knew who was sick or dead with AIDS (86\%) and knew who were at risk of HIV infection (65.5\%). All male youth had heard about AIDS and a high percent of them knew someone dead or sick with AIDS (92.2\%) and were at risk of infection $(71.7 \%)$. The Table shows that male youth have significantly high knowledge of deaths due to HIV/AIDS or patients with HIV/AIDS than their female counterparts $(p=0.002)$. This could be because of the majority of the male youth living in urban areas where HIV/AIDS information is more available compared to the rural areas where their female youth mostly live. Greater mobility among male than female youth may be another reason.

Table 2 Percentage of respondents with knowledge on HIV/AIDS by sex

\begin{tabular}{|c|c|c|c|c|}
\hline Variables & Males & Females & All & $\mathrm{p}$-value \\
\hline \multicolumn{5}{|c|}{ Heard of AIDS } \\
\hline Yes & 100.0 & 96.7 & 97.7 & 1.000 \\
\hline No & 0.0 & ०.० & 2. & \\
\hline \multicolumn{5}{|c|}{ Know someone with AIDS } \\
\hline Yes & 92.2 & 81.5 & 86.0 & 0.002 \\
\hline No & 7.8 & 18.5 & I & \\
\hline \multicolumn{5}{|c|}{ At risk of HIV infection } \\
\hline Yes & 71.7 & 62.6 & 65.5 & $0.6 \square$ \\
\hline No & 28. & $\square 7.4$ & {$[4.5$} & \\
\hline
\end{tabular}

Table $\square$ shows that overall the respondents were using the protection of sticking to one sexual partner $(6 \square .8 \%)$ followed by protected sex $(24.2 \%)$, and abstinence $(6.7 \%)$. Those who did not know any method of protection were $5.4 \%$. These results show that less than $7 \%$ of the respondents abstain from sex which implies that youth begin sexual intercourse at a very young age. It is worth noting that none of the adolescents aged $15-19$ years was abstaining, $\square 2 \%$ were using condoms. This is a worrying phenomenon for the future health of these youth due to their early indulgence in sexual intercourse. This may be because the young adults are already in steady relationships such as 
marriages and cohabitation. Two thirds of those aged $20-24$ years $(65 \%)$ were faithful to their partners than adolescents $(51 \%)$ which is much higher than the protected sex. There was no significant variation between the two age groups $(p=0.802)$.

Table 3 Percent of respondents who have protected themselves or their partners against HIV by background characteristics

\begin{tabular}{|c|c|c|c|c|c|}
\hline $\begin{array}{l}\text { Background } \\
\text { variables }\end{array}$ & Abstinence & Faithfulness & $\begin{array}{l}\text { Protected } \\
\text { sex }\end{array}$ & Nothing & p-value \\
\hline \multicolumn{6}{|l|}{ Age group } \\
\hline $15-19$ & 0.0 & 51.0 & $\square 2.2$ & 16.9 & 0.802 \\
\hline $20-24$ & 5.1 & 65.4 & $21 . \square$ & 8.2 & \\
\hline \multicolumn{6}{|l|}{ Sex } \\
\hline Male & 1.2 & $45 . \square$ & $\square 7.6$ & 15.9 & $0.97 \square$ \\
\hline Female & 0.7 & 69.1 & $19 . \square$ & 7.9 & \\
\hline \multicolumn{6}{|l|}{ Residence } \\
\hline Urban & 10.1 & $51 . \square$ & $\square 5.6$ & $\square .0$ & 0.580 \\
\hline Rural & 8.5 & 69.5 & 20.4 & 1.6 & \\
\hline \multicolumn{6}{|l|}{ Education } \\
\hline None & 21.1 & 48.5 & 18.4 & 12.0 & 0.000 \\
\hline Primary & 7.8 & 6ロ.4 & $2 \square .5$ & $5 . \square$ & \\
\hline Secondary & 2.8 & 64.1 & 25.1 & 4.0 & \\
\hline Tertiary & 1.8 & 65.0 & 25.2 & 8.0 & \\
\hline \multicolumn{6}{|l|}{ Sub-Region } \\
\hline North East & 4.4 & 66.9 & 26.7 & $\square .0$ & 0.12 \\
\hline North Central & 2.7 & 46.7 & $\square 9.6$ & 11.0 & \\
\hline West Nile & 5.7 & 70.4 & 22.6 & I. & \\
\hline \multicolumn{6}{|l|}{ Religion } \\
\hline Catholics & 6.5 & 65.1 & 25.7 & I. & 0.881 \\
\hline Protestants & 8.8 & 60.8 & 27.1 & 4.7 & \\
\hline Moslems & 11.9 & 55.5 & 50.1 & 2.5 & \\
\hline \multicolumn{6}{|l|}{ Occupation } \\
\hline Peasants & 7.7 & 75.1 & 16.0 & 1.2 & 0.005 \\
\hline Business & 6.6 & 54.9 & $\square 7.0$ & 1.5 & \\
\hline Clerical work & 5.2 & $60 . \square$ & $\square$ & 4.0 & \\
\hline Casual work & 16.5 & 49.2 & $\square$ & $\square .0$ & \\
\hline \multicolumn{6}{|l|}{ Marital status } \\
\hline Never married & 1.0 & $\square 6.9$ & 58.6 & $\square .5$ & 0.002 \\
\hline Currently married & 6.9 & 69.2 & 20.6 & ๑.५ & \\
\hline Cohabiting & І & 46.7 & $\square 4.6$ & 5.5 & \\
\hline $\begin{array}{l}\text { Separated/divorced/ } \\
\text { widowed }\end{array}$ & 16.9 & 4ฤ.9 & 20.2 & 19.0 & \\
\hline ALL & 6.7 & $6 \square .7$ & 24.2 & 5.4 & \\
\hline
\end{tabular}


Only I.2\% male and $7.7 \%$ female youth were abstaining, $\square 7.6 \%$ male and 19 . $\%$ female were using condoms. This can be explained by the low negotiation skills for safer sex by the female youth. More female youth were faithful $(69.1 \%)$ compared to the male youth (45. ए\%). There was no significant relationship between sex and method of protection. $(p=0.97 \square)$. It is not surprising that more rural residents were more faithful to their partners $(70 \%)$ than the urban residents (5I\%). In contrast more urban residents were using condoms $(\square 5.6 \%)$ than the rural respondents $(20.4 \%)$ which is also expected since urban youth are more exposed to information about condoms than their rural counterparts. There was no significant association between the place of residence and method used for protection against HIV/AIDS $(p=0.580)$.

It is interesting to observe that the level of faithfulness and use of condoms increases with education of the youth. This is probably due to increased exposure of the youth to HIV/AIDS information and awareness through education. Table $\square$ shows that there was a strong significant association between method of protection used and level of education $(p=0.000)$.

Faithfulness was highest for peasants $(75.1 \%)$ and clerical workers (60. $\square \%)$ and lowest among business persons $(54.9 \%)$ and casual workers (49.2\%). The reason for these results may be the peasants having less money than the business persons with higher income to afford buying condoms and paying lodge fees among other reasons therefore no much need to be faithful. In contrast, abstinence was much lower among the business persons (6.6\%), clerical workers $5.2 \%$ while casual workers had the highest proportion abstaining (16.5\%). This pattern may reflect the low incomes of casual workers whose viable alternative of protection is abstaining. Table $\square$ shows a significant association between occupation and method of protection, $(p=0.005)$.

As expected, the never married were least faithful to their partners $(\square 7 \%)$ and the currently married were the most faithful (69\%). In addition, the never married youth had the highest rate of condom use $(58.6 \%)$ and only $1 \%$ of them were abstaining. Not surprising the separated, divorced and widowed had the highest percentage abstaining from sex (16.9\%) since they did not have regular sexual partners. There is a significant association between marital status of the respondents and the protective method used against HIV infection $(p=0.002)$.

The West Nile sub-region had the highest proportion (70.4\%) of respondents using faithfulness as a method of protection, followed by North East $(66.9 \%)$ and the North Central had the least $(46.7 \%)$. The North Central subregion had the highest proportion of respondents using condoms as a method of protection ( $\square 9.6 \%)$, followed by North East $(\square 9.6 \%)$ while West Nile had the least $(22.6 \%)$. The West Nile sub-region had the highest respondents abstaining $(5.7 \%)$ followed by North East $(4.4 \%)$ and the North Central had the least (2.7\%). Respondents in North Central region used nothing for protection (11\%) compared to North East $(\square .0 \%)$ and the West Nile (I.๑\%). This may be due to the war 
that exposed many youth to rape. There was a significant association between sub-region and method of protection $(p=0.12)$.

Most Catholics (65.1\%) used faithfulness as a method of protection, followed by Protestants $(60.8 \%)$ and the least were Moslems (55.5\%). Results in Table $\square$ show that there is no significant association between religion and method of protection $(p=0.88 \mathrm{I})$. Being allowed to have more than one wife, the moslem youth may already be having several regular partners which is not considered faithful by our definitions. Perhaps this maybe the reason higher percentages of moslems ( $\square 0 \%)$, than catholics (27\%) and protestants (26\%) reported using condoms.

Table 4 Mean number of sexual partners for male and female youth

\begin{tabular}{|c|c|c|c|c|c|c|}
\hline \multirow[t]{2}{*}{ Variable } & \multicolumn{3}{|l|}{ Males } & \multicolumn{3}{|l|}{ Females } \\
\hline & $\begin{array}{l}\% \text { who } \\
\text { had sex in } \\
\text { the past I } 2 \\
\text { months }\end{array}$ & $\begin{array}{l}\% \text { who had } \\
2+ \\
\text { partners in } \\
\text { the past I } \\
\text { months } \\
\text { (among } \\
\text { men who } \\
\text { had sex in } \\
\text { the past I2 } \\
\text { months) }\end{array}$ & $\begin{array}{l}\text { Meanno. } \\
\text { of life } \\
\text { time } \\
\text { sexual } \\
\text { partners }\end{array}$ & $\begin{array}{l}\text { \% who } \\
\text { had sex } \\
\text { in the } \\
\text { past } 12 \\
\text { months }\end{array}$ & $\begin{array}{l}\text { \% who had } \\
2+\text { partners } \\
\text { in the past I2 } \\
\text { months } \\
\text { (among } \\
\text { women who } \\
\text { had sex in the } \\
\text { past I2 } \\
\text { months }\end{array}$ & $\begin{array}{l}\text { Mean no. } \\
\text { of life } \\
\text { time } \\
\text { sexual } \\
\text { partners }\end{array}$ \\
\hline \multicolumn{7}{|l|}{ Age group } \\
\hline $15-19$ & 51.6 & 26.1 & $\square .2$ & 45.4 & 6.5 & 1.5 \\
\hline $20-24$ & 84. & $\square 6.8$ & 5.4 & 81.7 & $\square .2$ & 1.8 \\
\hline \multicolumn{7}{|l|}{ Residence } \\
\hline Urban & 64. $\square$ & $\square 2.1$ & 7.1 & 57.4 & 7 & 2. $\square$ \\
\hline Rural & 7П.6 & 26.5 & 5.2 & 72.4 & $\square .9$ & 2.2 \\
\hline \multicolumn{7}{|l|}{ Education } \\
\hline None & 86.9 & 25.1 & 6.8 & 87.6 & 2.9 & 2.1 \\
\hline Primary & 74.9 & 28. & 7 & 74.8 & 4.1 & 2.2 \\
\hline Secondary+ & 6ロ. & $\square 0.6$ & 7.1 & 66.2 & 5.7 & 2.2 \\
\hline \multicolumn{7}{|l|}{ Sub-Region } \\
\hline North East & 75.1 & 15.7 & ๑.૫ & 77.8 & 7.9 & 1.6 \\
\hline North Central & 78. $\square$ & $2 \square .2$ & 5.9 & 87. & 20.4 & 1.7 \\
\hline West Nile & 62.1 & 24.1 & 4.7 & 65.7 & 6.7 & 1.6 \\
\hline \multicolumn{7}{|l|}{ Marital status } \\
\hline Never married & 6ロ.4 & ㅁ. & 6.8 & 41.9 & 20.0 & 1.4 \\
\hline Currently married & 99.1 & 27.5 & 8.5 & 98.0 & 2.1 & I.7 \\
\hline $\begin{array}{l}\text { Separated/divorced/ } \\
\text { widowed }\end{array}$ & $\square$ & 24.4 & $\square .2$ & 22.5 & 10.7 & 2.5 \\
\hline All & 69.9 & 27.1 & 5.7 & 67.6 & 7.8 & 1.9 \\
\hline
\end{tabular}


The major indicator of sexual behavior are the number of sexual partners with whom the youth had sex in the last 12 months, the type of relationship they had with these partners and the number of sexual partners in their whole life. Table 4 summarises the responses of respondents. Overall $69.9 \%$ of the male and $67.6 \%$ of the female youth had had sex in the past 12 months. Of these $27.1 \%$ male youth had had sex with $2+$ partners in the past 12 months, much higher than $7.8 \%$ of the female youth.

Table 4 shows that the number of sexual partners increased with age. Adolescents (15-19 years) had 2. $\square$ life time sexual partners, while the youth (20-24 years) had $\square .6$ sexual partners. On average, the proportion of adolescents who had had sex in the past 12 months was $48.5 \%$ compared to $8 \square \%$ of the youth 20-24 years who had had sex in the past 12 months.

Female adolescents (15-19 years) had 1.5 life time sexual partners and those aged 20-24 had 1.8 compared to the male youth (15-19 years) who had 0.2 life time sexual partners and 5.4 sexual partners for male youth aged 20 24 years. Implied in this is that, male youth had twice as many life time sexual partners as compared to their female counterparts. $26.1 \%$ female adolescents and $\square 6.8 \%$ male youth (2024 years) had $2+$ sexual partners in the past 12 months compared to only $6.5 \%$ female adolescents and $0.2 \%$ female youth (20-24 years).

Table 4 shows that $70 . \square \%$ rural and $60.9 \%$ urban youth had sex in the past 12 months. $19.6 \%$ urban youth had $2+$ partners in the past 12 months compared to $15.2 \%$ rural youth. Urban youth had more life time sexual partners (4.7) than rural youth had (․7).

Youth with no education had a lower number of sexual partners (4.5) compared to the primary (4.6) and post-secondary (4.7). Number of sexual partners increased with increasing education. This may be due to the fact that youth with no education have held onto the cultural values of abstinence as compared to those who are educated and therefore have perhaps been exposed to media that has changed their attitudes. However youth with no education (87. (-) reported to have had sex in the past 12 months compared to $74.9 \%$ with primary education and $64.8 \%$ with secondary education. This may be due to increased information among the youth in school on issues of HIV/AIDS.

The table shows that currently married male youth had the most multiple partners (8.5) compared to the separated/ divorced ( $\square .2$ ) and the never married (6.8). This partly explains why HIV prevalence is highest among the married people compared to other categories.

Table 5 shows a big difference in the condom use by age groups. $\square 2.2 \%$ of the adolescents used condoms at last sex compared to young adults (19\%). The difference may be due to older who might be in stable unions compared to the adolescents. However, there is no significant association between age and condom use $(p=0.62 \square)$.

As observed in the table, much higher proportion of males ( $\square 7.6 \%)$ than females (14.]\%) used condoms in Northern Uganda. This might be due to the low bargaining power for safer sex 
of females than males and the more exposure to information by males than females. There is a strong significant association between sex and use of condoms $(p=0.000)$. Only $\square 5.6 \%$ of youth in urban areas were found to be using condoms, compared to rural respondents (14.8\%). This is in con- formity with other studies and can be partly explained by the easier access to condoms in the urban areas than in rural areas. There is a significant association between residence and condom use $(p=0.00 \mathrm{I})$ by youth in Northern Uganda.

Table 5 Condom use at last sex among those who had sex in the 12 months preceding the survey

\begin{tabular}{|c|c|c|}
\hline Age group & Used Condoms & $\mathrm{p}$-value \\
\hline $15-19$ & $\square 2.2$ & $0.62 \square$ \\
\hline $20-24$ & 19 & \\
\hline \multicolumn{3}{|l|}{ Sex } \\
\hline Male & $\square 7.6$ & 0.000 \\
\hline Female & 14.0 & \\
\hline \multicolumn{3}{|l|}{ Residence } \\
\hline Urban & $\square 5.6$ & 0.001 \\
\hline Rural & 14.8 & \\
\hline \multicolumn{3}{|l|}{ Education } \\
\hline None & 9.4 & 0.000 \\
\hline Primary & 19.4 & \\
\hline Secondary & 26.1 & \\
\hline Tertiary & $\square 9.4$ & \\
\hline Sub-Region & & 0.780 \\
\hline North East & $2 \square .7$ & \\
\hline North Central & Ш.6 & \\
\hline West Nile & 17.9 & \\
\hline \multicolumn{3}{|l|}{ Religion } \\
\hline Catholics & ID. & 0.008 \\
\hline Protestants & 29.7 & \\
\hline Moslems & {$[4.1$} & \\
\hline \multicolumn{3}{|l|}{ Occupation } \\
\hline Peasants & 12.1 & 0.000 \\
\hline Business & 29.9 & \\
\hline Clerical work & प7.० & \\
\hline Casual work & 21.7 & \\
\hline \multicolumn{3}{|l|}{ Marital status } \\
\hline Never married & 40.2 & 0.000 \\
\hline Currently married & I & \\
\hline Separated/divorced/widowed & 20.7 & \\
\hline All & 24.9 & \\
\hline
\end{tabular}


Condom use was highest among respondents with post secondary schooling $(\square 9.4 \%)$ compared to those with primary (19.4\%) and none (9.4\%). This is because those with no education tend to cling to their cultural beliefs and practices and therefore shun the use of condoms. The association between education and condom use is highly significant $(p=0.000)$. Condom use at last sex was highest in North Central region (प.6\%), followed by North East (2】.7\%) and West Nile (I7.9\%). There was no significant association between region and condom use.

As might be expected, the never married were most likely to have used a condom at last sex $(40.2 \%)$ compared to those separated/divorced/widowed $(20.7 \%)$ and those currently married (I $\square .4 \%$ ). Low usage of condoms among currently married might be due to the trust that they have in their partners unlike the never married. At multivariate stage of analysis, the logistic regression model was fitted to examine the significance of socio economic and intermediate variables on condom use. The regression results of condom use on age, sex, education, marital status, residence, knowledge of one with AIDS, risk perception to HIV infection and heard of AIDS are shown in Table 6. The relationship between condom use and independent variables is discussed in this paper. As shown in Table 6 , respondents in the age group 20-24 were 2.2 times more likely than those aged 15-19 (reference category) not to use condoms. Age group 20-24 also has an R-value of 0.1054 , which shows that there is a relationship between the age of a respondent and their use of condoms.
It can be concluded from these results that adolescents are more likely to use condoms than older youth. This may be because young adults frequently have sex with regular partners, usually their wives, and therefore do not feel the need to use condoms. On the other hand, adolescents engage in sexual encounters with multiple partners for adventure. Adolescents often do not have regular partners and in cases where they do, they are not faithful to them. This necessitates them to use condoms as a mode of protection from unwanted pregnancy, STDs and HIV/ AIDS.

Results show that female youth are 7.5 times more likely not to use condoms than men (reference group). The table also shows that there was a strong association between sex and condom use $(p=0.000 \mathrm{I})$. The R-statistic of 0.1887 also indicates a relationship between the sex of the respondent and their condom use.

The results are not surprising, considering that condoms commonly available were designed for men. The low bargaining power by women in sexual matters due to low social status and dependence on the opposite sex also explain the results. Cultural norms and beliefs which emphasize men making decisions in particular those related to sexual matters which leaves women with no say.

Table 6 shows that rural residents were $[$.$] times more likely not to use$ condoms than the people in urban areas. There is a high statistical relationship between residence and condom use $(p=0.0007)$. These results are explainable by reasons of inaccessibility and unaffordability of condoms in rural 
areas, as well as the fact that rural residents have a higher level of faithfulness and this reduces the need for condom use.

Table 6 Results of logistic regression of condom use at last sex on selected variables

\begin{tabular}{|c|c|c|c|c|}
\hline Variable & & Sig & $\mathrm{R}$ & $\operatorname{Exp}()$ \\
\hline \multicolumn{5}{|l|}{ Age } \\
\hline $15-19 * *$ & 0.0000 & - & - & 1.0000 \\
\hline $20-24$ & 0.7700 & 0.0057 & 0.1054 & 2.1597 \\
\hline \multicolumn{5}{|l|}{ Sex } \\
\hline Male*** & 0.0000 & - & - & 1.0000 \\
\hline Female & 1.1806 & 0.0001 & 0.1887 & $\square .4550$ \\
\hline \multicolumn{5}{|l|}{ Residence } \\
\hline Rural*** & 0.0000 & - & - & 1.0000 \\
\hline Urban & $1.195 \square$ & 0.0007 & $0.14 \square$ & ‥ $\neg 861$ \\
\hline \multicolumn{5}{|l|}{ Education } \\
\hline Secondary*** & 0.0000 & - & - & 1.0000 \\
\hline None & $0.91 \square 2$ & $0.04 \square 5$ & 0.0517 & $2.476 \square$ \\
\hline Primary & $0.765 \square$ & $0.01 \square 7$ & 0.0875 & 2.1654 \\
\hline \multicolumn{5}{|l|}{ Religion } \\
\hline Moslem*** & 0.0000 & - & - & 1.0000 \\
\hline Catholic & $0.654 \square$ & 0.0621 & 0.0521 & $1.9 \square 46$ \\
\hline Protestant & $0 . \square 150$ & $0 . \square 227$ & 0.0000 & 1.2901 \\
\hline \multicolumn{5}{|l|}{ Occupation } \\
\hline Business*** & 0.0000 & - & - & 1.0000 \\
\hline Peasant & 0.9168 & 0.0112 & $0.8 \square 00$ & $2.52 \square 6$ \\
\hline Clerical work & 0.2548 & $0.5 \square 49$ & 0.0000 & I. .7885 \\
\hline Casual Labor & 0.7845 & 0.0125 & 0.0849 & 2. $\square 186$ \\
\hline \multicolumn{5}{|c|}{ Marital status } \\
\hline Other米 & 0.0000 & - & - & 1.0000 \\
\hline Never married & $0 . \square 750$ & 0.4750 & 0.0000 & I.469| \\
\hline Married & $0.674 I$ & 0.0279 & 0.0721 & 1.9589 \\
\hline \multicolumn{5}{|c|}{ Knowledge of one dead or sick with AIDS } \\
\hline No*** & 0.0000 & - & - & 1.0000 \\
\hline Yes & І. $\square 575$ & 0.0122 & $0.09 \square 2$ & 4.7194 \\
\hline \multicolumn{5}{|c|}{ Perception of risks to HIV infection } \\
\hline No*** & 0.0000 & - & - & 1.0000 \\
\hline Yes & 0.8257 & 0.0041 & 0.1097 & 2.4066 \\
\hline \multicolumn{5}{|c|}{ Heard of HIV/AIDS } \\
\hline No*** & 0.0000 & - & - & 1.0000 \\
\hline Yes & -1.2196 & $0.264 \square$ & 0.0000 & 0.2417 \\
\hline
\end{tabular}

Key $=$ Reference category - Logistic co efficient

$\mathrm{R}=$ partial correlation co efficientExp ()= Odds ratio 
In addition, the table shows that condom use increases with increasing education. Respondents with no education were 2.5 times more likely not to use condoms than those in primary school (2.2 times). Both categories are significant at $\mathrm{p}<0.05$, but primary education is more significant $(p=0.0107)$.

Table 7 Results of logistic regression of willingness to test for HIV on selected variables

\begin{tabular}{|c|c|c|c|c|}
\hline Variable & B & Sig & $\mathrm{R}$ & $\operatorname{Exp}(B)$ \\
\hline \multicolumn{5}{|l|}{ Sex } \\
\hline Male*** & - & - & - & - \\
\hline Female & $0.9 \square 88$ & 0.0075 & 0.1211 & 2.567 \\
\hline \multicolumn{5}{|l|}{ Marital status } \\
\hline Never married & 0.8245 & $0.1 \square 56$ & 0.0401 & 2.27ロI \\
\hline Married & -0.2745 & $0.4 \square 56$ & 0.0000 & $0.812 \square$ \\
\hline Separated/divorced/widowed*** & - & - & - & - \\
\hline
\end{tabular}

Key

*** Reference category

B- Logistic co efficient

$R=$ partial correlation co efficient

$\operatorname{Exp}(B)=$ Odds ratio

A higher level of education promotes condom use through increased awareness of how to use condoms, the benefits of condom use, increased bargaining power for women and the dangers of not using condoms. Odds ratio for nonuse of condoms was highest for peasants (2.5) followed by casual laborers (2.】) and finally clerical workers (1.4). Peasants were more likely not to use condoms $(p=0.0 \mathrm{I} / 2)$ than casual laborers $(p=0.0125)$. In table $\square$, the means of protection against HIV for peasants was faithfulness. Peasants are largely from rural areas and as earlier mentioned, these do not have access to condoms. Furthermore condoms cost money and the income of peasants is not enough to support regular condom use.

Married youth were twice as likely as those separated, divorced or widowed not to use condoms. There is statistical relationship between the category of youth who had been mar- ried before and condom use. The marital status is related highly to non use of condoms because in marriage people assume faithfulness and the never married are expected to use condoms as they are having sexual intercourse with casual and non regular partners.

There is no significant relationship between being a protestant and condom use. The R-statistic of 0.0521 shows a weak contribution of being a catholic to condom use. Catholics were also twice as likely as Moslems were not to use condoms. The negative beta co efficient suggests no contribution of variable to condom use. There is also no significant relationship between never having heard of HIV/AIDS and condom use $(p=0.8257)$. Willingness to test for HIV was regressed on the selected variables. As shown in Table 7 it was found out that apart from sex and marital status all other variables did not contribute to the model $(R=0.0000)$. (They are therefore not shown in the 
table).

Results show that the sex of respondents was significantly related to willingness to test for HIV at $p<0.05$ while marital status was not.

Female youth were 2.6 times more unwilling than the males to be tested for HIV. There is a statistical association between females and unwillingness to test $(p=0.0075)$. This can be explained by the African culture where males make decisions for females hence female youth cannot decide whether or not to go an HIV test. It may also be due to cost of an HIV and women have less money than men available to pay for an HIV test. The Table shows a negative beta coefficient $(-0.2745)$ and $p>0.05$ for married respondents. This means that there is no relationship between marriage and willingness to test. The R-statistic for the never married youth is $0.040 \mathrm{I}$ implying that there is some contribution of marital status to unwillingness to test. There is no significant association between marital status and willingness to test $(p>0.05)$.

This may be due to low perceptions of the risk in contracting HIV among married youth as a result of faithfulness hence rendering HIV tests irrelevant. Never married youth have higher risk perceptions to getting HIV/AIDS as their sexual behavior is not safe hence a lower level of willingness to test. There was significant statistical relationship between background, socio-economic factors, intermediate variables of risk perception, knowledge of one dead or sick of AIDS and condom use at multivariate level. Behavior in the form of condom use is a function of all variables though sex, education, residence and perception to risk of HIV infection had the greatest influence.

Willingness to be tested is a function of only sex which showed a statistical relationship. Apart from religion and age, all other factors (sex, residence, education, occupation, marital status, perception of risks to HIV infection and knowledge of one dead or sick with AIDS,) were found to affect condom use with sex and residence of respondents exerting the greatest influence. On the contrary only sex was found to be significantly associated to willingness to test.

\section{Discussion}

The study confirmed that residence was significantly related to condom use at all levels of analysis. The hypothesis that youth residing in urban areas were more likely to be more knowledgeable, have more favorable attitudes and practice contraception more than their rural counterparts was true. The spread of HIV between areas and within areas is specifically correlated with the risk factors including injection drug use, use of drugs such as cocaine, exchange of sex for money, and the rates for sexually transmitted diseases. All of these factors are shown to increase the risk of HIV so that the constellation of these practices helps determine the differential rates and spread of HIV in rural compared to urban areas. However youth particularly in rural areas have low knowledge about HIV/AIDS and its mode of transmission compared to their urban counterparts. This is further accelerated by the clear rural-urban differential among youth regarding their educational attainment which ultimately contributes to the levels of knowledge.

The study suggests that education is 
paramount in sexual behavior even after controlling for effects of having heard of AIDS, knowledge of someone with AIDS and risk perception to HIV infection. Education improves one's knowledge about AIDS. It also changes individual attitude from traditional beliefs of witchcraft to accurate thinking. Education also advances the bargaining power of women and therefore gives them an edge over controlling their sexual behavior. In view of the above, the hypothesis that the higher the education of an individual, the more knowledgeable about HIV/AIDS is true.

Religion was also found not to be significantly related to knowledge, attitudes and behavior of youth hence the hypothesis that knowledge, attitudes and practices towards HIV/AIDS do not vary much between religious denominations is true. The study verified that marital status was significantly related to the protective method used against HIV infection. The never married were least faithful to their partners and the currently married were the most faithful. In addition, the never married youth had the highest rate of condom use and only $1 \%$ of them were abstaining. It is not surprising that the separated, divorced and widowed had the highest percentage abstaining from sex.

There is a need to build on whatever successes we have achieved so far in reducing the HIV prevalence rate. However, it is still alarmingly high and unless a continued effort is made to keep people aware of the dangers of HIV then it would be quite possible for prevalence rate to remain at this level or even increase again. There is some evidence that such a rise is already taking place, possibly because people are becoming more complacent about HIV.

There is no straightforward system for reducing the number of new HIV infections, as a number of different interventions are required. Foremost among these are promoting balanced abstinence, being faithful and using condoms (ABC approach), committed political leadership, willingness to discuss openly HIV transmission and prevention, and vigorous campaigns in rural communities in Northern Uganda. The challenges faced by the youth are several including low quality education, lack of marketable skills, high rates of unemployment, crime, early pregnancy and social exclusion, as shown in the analysis. These are often costly to themselves and the society at large. Strategies for policy advice on how to tap the enormous potential of youth in war torn areas should be strengthened.

Young people are at the heart of the HIV/AIDS pandemic. Not only are they disproportionately represented in terms of new infections, but they are also key to overcoming the disease. Effective HIV prevention efforts that focus on youth are crucial to reversing the pandemic in Northern Uganda. Analysis showed that many young people still do not know how to prevent HIV infection. Although today's youth are much more informed about HIV/ AIDS any preceding cohort, even in countries with a generalized pandemic, more than $80 \%$ of young women still do not have "sufficient understanding" about how to avoid HIV. The real challenge, however, consists in changing risky behaviors: even among those who know that condoms prevent HIV, few actually use them. Decreasing the disease burden and mortality in youth 
people preserves their human capital. Moreover, preventing infection is much less costly than treatment-for every life year gained with anti-retroviral therapy, 28 life years could have been gained through prevention. Finally, since many young people are parents themselves, preserving their health benefits their children, too.

Education is a powerful protective factor against HIV infection and should therefore be promoted. Education provides youth with aspirations for their future, increases their expectations of future earnings, increases their ability to process health-related information and empowers them to make informed decisions. Data Analysis in chapter five showed that educational attainment is positively correlated with condom use, use of counseling and testing, knowledge about HIV and AIDS in Northern Uganda. On average, girls who are better educated are less likely to be infected with HIV.

Youth should be involved in the intervention design in order to assure relevance of programs to them. The success of Youth-specific interventions often depends greatly on how the youth relate to their service provider and, in turn, how those providers and institutions succeed in empowering and integrating youth. There is now a wide consensus about the main settings through which young people can be reached with preventive interventions: schools, peers, health services, mass media and geographically defined communities. There is also a growing research base on the effectiveness of specific youth interventions within these settings. Of particular note is a systematic review of evaluated evi- dence from developing countries on preventing HIV/AIDS in youth carried out by the UNAIDS Interagency Task Team on Young People. Some of the key messages from this review and related research are: School-based programs can be effective in improving youth's knowledge of HIV/AIDS and reducing risky behavior. This implies that teachers should be sufficiently trained and encouraged to use interactive teaching methods and that they do not hesitate to address sexual matters explicitly. Also, starting well-designed reproductive health education even before the onset of sexual activity prevents risky behavior and allows programs to reach adolescents who do not remain in school later on

Making health services more youthfriendly may lead to an increased use of facilities by young people in Northern Uganda. Many young people lack access to services such as condoms and voluntary counseling and testing (VCT). Often socially excluded or out-ofschool youth are reluctant to go to a clinic, so services need to go to them where possible, such as in the workplace, job training programs, social venues, sports settings and in communities. Sensitizing health staff on young peoples' needs is critical to make sure they get the service package they need.

Targeted media and social marketing campaigns should be used in communities to improve young people's knowledge about HIV and AIDS. Programs that use a mix of media show significant outcomes on HIV knowledge and skills as well as on condom use. Higher levels of program exposure increase the likelihood of behavior change. Training peers to be positive 
role models that can positively influence young peoples' behaviors, facilitating access to and creating trust among young people. Peer education and other community-based programs are especially effective in reaching out-ofschool youth and other groups particularly vulnerable to infection. The most noTable impacts have been in increasing HIV/AIDS awareness and in improving some behavioral indicators such as increased condom use at last sex (e.g. Peru peer promotion program, Nigeria project with youth serving organizations and peer education program in Cameroon).

\section{Conclusion}

The future of the HIV pandemic lies in the hands of young people, and the need to scale up programs targeting this group is clear. The behaviors they adopt now and those they maintain throughout their sexual lives will determine the course of the pandemic for decades to come. The new evidence base for what works in preventing HIV/AIDS in young people can help guide policymakers and practitioners to make better-informed choices in giving young people the attention they warrant and to accelerate action to achieving global goals.

Nevertheless while the knowledge base regarding successful programs has been steadily growing over the last decade, several large research gaps remain. Surveillance and monitoring data on youth are often unavailable, and rigorous evaluations on youth HIV prevention programs in developing countries remain rare. The few that are available tend to focus only on small-scale programs. Further, they rarely measure biological markers such as HIV preva- lence in the target population, but focus instead on behavioral outcome indicators, such as self-reported condom use or decrease in sexual activity. Approaches that deserve particular evaluation attention include youth-friendly clinical services and those linking livelihoods interventions and HIV prevention.

Finally, cost-effectiveness and costbenefit analyses are still scarce for all types of approaches. Further operational research in this direction is crucial to inform policy makers about the merits of choosing or continuing a given intervention.

\section{References}

Centers for Disease Control and Prevention (CDC) (1995); Morbidity and mortality weekly report (MMWR): Case control study of HIV sero-conversion in health care workers after percutaneous ex-posures to HIV infected blood; France, UK, and US. 44: pages 929-9 I

Centers for Disease Control and Prevention (CDC) (2005); Exposure to Blood: What Health-Care Workers need to know, pages I-2

Centers for Disease Control and Prevention, (1999); HIV/AIDS surveillance report, pages I-44

Children \& Youth Unit, Human Development Network, Nepal, The World Bank, November 2006

Clever, L.H. and LeGuyader, Y. (1995) Infection risks for health care workers. Annual review of public health, 16: pages 142-159

Family Health International, Youth Peer Education in Reproductive Health and HIV/AIDS: Progress, Process, and Programming for the Future, 


\section{6}

Hogle, J.A and Green, E. (2002) Project lessons learned case study; What happened to Uganda? Declining HIV prevalence, behavioural change, and the national response. USAID, pages 2-5.

Ministry of Health, $(\mathrm{MOH})(200 \square)$, STD/HIV/AIDS surveillance report for Uganda, Epidemiology / Surveillance unit STD/ACP, pages 19 \& $\square$.

Ministry of Health, (MOH) (200ワ), STD/HIV/AIDS surveillance report for Uganda, Epidemiology / Surveillance unit STD/ACP, pages 19 \& $\square 0$.

Ministry of Health, (MOH) (2004/5) Uganda HIV/AIDS Sero-Behavioural Survey (UHSBS)

Mitsui, T. and Iwano, K. (1992) Hepatitis $C$ virus infection in medical personnel after needle stick accident. Hepatology, 16: pages I I07-I I 20

Ndoleriire, S. (199】) Knowledge, attitudes, practices and beliefs of health personnel regarding nosocomial AIDS-HIV infection in five hospitals in Eastern Uganda. Tororo, Iganga and Mbale districts, pages 0-10. MMed (Community Practice) dissertation, Makerere University, Kampala.

Situation Analysis 2002, Uganda AIDS Commission Surveillance report 2002.

The effects of the Katakwi/Soroti School health and AIDS prevention project. AMREF report, Kampala. August 200I.

Uganda Bureau of Statistics, (UBOS) (2002); 2002 Census Results. Online http://www.ubos.org/ 2002censusresults.html,

Uganda Bureau of Statistics, (UBOS) (2006); Uganda Demographic and Health Survey Report

UNAIDS. 006. Report on the Global AIDS Epidemic 2006. New York: UNAIDS

UNICEF CEE/CIS and Baltics Regional Office. February 004. HIV/AIDS in Europe and Central Asia. Press Release.

UNICEF, UNAIDS, WHO. 00 . Young People and HIV/AIDS Opportunity in Crisis. New York: UNICEF. 